\title{
Travail et technique chez les Grecs. L'approche de J.-P. Vernant
}

\section{Charles Kanelopoulos}

\section{(2) OpenEdition}

1 Journals

Édition électronique

URL : https://journals.openedition.org/tc/670

DOI : $10.4000 /$ tc. 670

ISSN : 1952-420X

Éditeur

Éditions de l'EHESS

\section{Édition imprimée}

Date de publication : 1 mai 1993

ISSN : 0248-6016

\section{Référence électronique}

Charles Kanelopoulos, «Travail et technique chez les Grecs. L'approche de J.-P. Vernant », Techniques \& Culture [En ligne], 19|1993, mis en ligne le 10 janvier 2006, consulté le 29 septembre 2022. URL:

http://journals.openedition.org/tc/670 ; DOI : https://doi.org/10.4000/tc.670

Ce document a été généré automatiquement le 29 septembre 2022.

Tous droits réservés 


\section{Travail et technique chez les Grecs. L'approche de J.-P. Vernant}

Charles Kanelopoulos 